\title{
Teologia, cultura e literatura: uma análise da hamartiologia implícita na obra Hamlet, de Shakespeare, a partir da teologia da fronteira de Paul Tillich
}

\author{
Brayan de Souza Lages* \\ Samuel Rodrigues dos Santos**
}

\section{RESUMO}

Analisar seletas questões hamartiológicas contidas em Hamlet - a partir de uma abordagem dialógica entre Teologia, Cultura e Literatura - é o objetivo central do artigo em tela. Desse modo, o mesmo se inicia com caráter preambular - ou antes de andar - elencando e esclarecendo alguns fatores que construíram o background do cenário em que vivia Shakespeare. Num segundo momento, este artigo se projeta a delinear a teologia tillichiana, aclarando, sumariamente, dois conceitos clássicos de seu labor - Teologia da Cultura e Coragem de Ser -; chegando ao fim, onde se propõe correlações entre as ansiedades ou angústias de Hamlet e as respostas de Tillich, como também se argui sobre o problemático suicídio de Ofélia.

Palavras-chave: Hamlet; Shakespeare; Paul Tillich; hamartiologia; teologia da fronteira.

* Doutorando em Teologia Sistemática pela PUC-Rio (2019). Mestrado em Ciências da Religião pela UNIDA (2016). Graduação Teologia pela FAECAD (2014). Graduação em Administração pela Universidade do Grande Rio (2011). Tem experiência na área de Ciências da Religião e Teologia. Dedica-se ao estudo da Teologia Sistemático-Pastoral, Ética, Metodologia Científica, Militarismo e Religião, Teologia Pública e Religião na Esfera Pública. Atua como professor da graduação e pós-graduação da FAECAD desde 2017. E-mail: brayanlages@gmail.com.

** Bacharel em Teologia pela Faculdade Evangélica de Tecnologia, Ciências e Biotecnologias da CGADB (FAECAD). Tendo experiência na área de Teologia, com ênfase em Teologia Sistemática e suas relações com as Literatura e Atualidade. E-mail: samuelrodriguesdossantos770@gmail.com. 


\title{
Theology, Culture and Literature: an Analysis of the implied Ha- martiology in Shakespeare's Hamlet, According to Paul Tillich's Boundaries Theology
}

\begin{abstract}
This paper analyzes, from a dialogical approach between theology, culture and literature, selected hamartiological issues in Hamlet. First, starting with a preambular character, listing and clarifying some built-factors for background scenario in which Shakespeare lived. In a second step, the paper is designed to outline Tillichian theology, briefly clarifying two classic concepts of his work, i.e., Theology of Culture and The Courage To Be. Eventually, it proposes correlations between Hamlet's anxieties or anxieties, and Tillich's responses are as well proposed about Ophelia's problematic suicide.

Key words: Hamlet; Shakespeare: Paul Tillich; Hamartiology; Boundaries Theology.
\end{abstract}

\section{Introdução}

"Cristandade não se confunde com cristianismo" (AGOSTINHO, 2013, p.15). Enquanto o último vive para organizar e impor os padrões de comportamentos que possam caracterizar um destinado grupo, o primeiro fala da Graça, do advento da liberdade dos filhos de Deus. Assim, nas palavras de Emmanuel Carneiro Leão - sintetizadas acima - a Cristandade é e têm sido a caminhada da "libertação da verdade" de Deus nas chegadas históricas (AGOSTINHO, 2013). Essa compreensão dual da vida cristã se faz base para a inserção das discussões shakespearianas que se inserem num contexto caótico, onde não se distingue a essência do ser cristão, das normas que são puramente culturais. Onde as guerras religiosas tomavam espaço na vida, em detrimento da verdade.

Entrementes, se torna imprescindível à temática a análise do texto célebre Hamlet em face ao cristianismo de sua época. Pois é mister compreender o contexto vital das obras de Shakespeare, uma vez que a realidade político-religiosa influenciou diretamente no pensamento do autor, visto que o período elisabetano é circunscrito por crises que são latentes nas tragédias desse dramaturgo. Como asseverou Cordeiro, "apesar de Shakespeare ter vivido em dias de protestantismo, não se há que olvidar dos dias que lhe sucederam, os quais, à sombra de um trono católico, certamente legaram àqueles, parte de si" (CORDEIRO, 2018). Compreendendo, assim, uma dualidade que nascia numa gama 
religiosa e se estendia para todas as esferas do social. Contudo, existem fatores precedentes que norteiam as concepções religiosas concebidas por Shakespeare, no período régio da Virgem.

Desse modo, se estende uma hermenêutica a partir do teólogo prussiano Paul Tillich, que bem compreendia essa dualidade e suas confluências no encontro fronteiriço entre religião e cultura. Desde então, a heurística busca por uma resposta hamartiológica - mesmo que imersa em um novo conceito - em Hamlet, se faz valer, por via da construção teologal do teuto-americano.

\section{A interface entre o cristianismo e a hamartiologia em Hamlet}

\subsection{Contexto politico-religioso da Europa reformista}

Grosseiramente, destacam-se duas esferas reformadoras que permearam a vida religiosa europeia, reanimando sua cultura espiritual. Movimentos de Reformas internas e externas são as duas classes ou esferas - podendo ser assim chamadas superficialmente - que transcorrem pela medievalidade vivificando-a nos moldes cristãos.

Os movimentos de reformas internas são caracterizados principalmente pelas classes mendicantes no século XII, marcadas por nomes como Francisco de Assis, São Domingos e Bernardo de Claraval. Tiveram, de fato, o intuito de purificar a Igreja que estava amalgamada com o Estado numa relação intrínseca que desaguava, em última instância, em abusos e prodigalidade por parte do clero em geral (DAWSON, 2016, pp. 245-246). Elas carregam essa alcunha, por não causarem cisão no resultado de sua proposta, mas, unicamente, vívida espiritualidade, esboçada em novas regras dirigentes de vida.

Por outro lado, as Reformas externas alçam esse cognome, pela resposta da Igreja Romana a seus movimentos, que contém em seu bojo, um conglomerado de outros fatores - e não somente os religiosos - carregando uma importância precípua para a compreensão do' background da literatura shakespeariana ${ }^{1}$. Nomes como os de Johannes Wycliffe e

\footnotetext{
Diante da extensão limitada do presente trabalho, não se fará um detalhamento desses fatores - a não ser, em raras exceções -, afinal, não é a intenção do mesmo. Contudo, o conhecimento das mudanças na estratificação social, pela ascensão e, por conseguinte, coalização da burguesia com a nobreza; das consequências da peste bubônica; da natureza bélica dos governos; e da imprecisão do papado, enquanto no período do cativeiro, na França, que implicou no aparecimento de movimentos antipapistas e nacionalistas. Formando num todo, o pano de fundo da nova Reforma - a externa, são informações imprescindíveis para a imersão no roteiro do bardo. (GONZÁLEZ, 2011)
} 
Huss foram os primeiros enleados para a inquisição, pela natureza de seus ensinos que divergiam da Igreja papal, tornando-os, perante esta, hereges.

Mexer no núcleo doutrinário da Igreja de Roma foi o que causou tamanha repercussão na vida desses ícones. No caso de Wycliffe, pode-se declarar que foi um implacável crítico da ordem heterônoma que era o papado ${ }^{2}$. À bem da verdade, o demolidor, grande polemista inglês, tinha um vínculo com a coroa - que o fizera de "castanhas na boca de um macaco" 3 - defendendo-a das ardilosas pretensões tributárias do pontificado romano. Duas especificidades de seus ensinos se destacam: a questão do senhorio e a Igreja invisível. O último tem como nascente e finalidade a Bíblia, pois, pelo encontro com os escritos de Agostinho e de Paulo, o polemista inglês concluiu que a Igreja era composta por um grupo de eleitos, predestinados; sendo assim, a verdadeira Igreja é invisível.

Não obstante, ele afirmava, partindo dessa premissa, que muitos dos clérigos de sua época são perdidos, em especial o papa ou, segundo ele, "o anticristo" (GONZÁLEZ, 2011a, p.491). Se os poderosos da hierarquia católica não são definitivamente a Igreja, a Bíblia precisa ser traduzida para quem o é, no caso, o povo inglês. Quanto ao verdadeiro senhorio, pode-se dizer que foi como uma faca de dois fios, cortando para o sacerdócio, mas, de forma alguma, eximindo o império de qualquer culpa. O único Senhor é Deus, e qualquer outra relação de sujeição ou serviço deve ser com o propósito de imitá-lo, na humildade da pessoa de Cristo. Assim que o trono viu a ambiguidade dessa assertiva, aceitou a condenação de ser ele herege, por divergir da Igreja católica, no que tange a eucaristia, legando-o um fim solitário. De qualquer modo, ele foi um personagem precípuo para a instauração da nova realidade medieval. Como vemos no memento e, ao mesmo tempo, na satisfação de Dawson:

2 "Foi ele quem, certamente, preparou o caminho para a reforma inglesa, e suas ideias foram amplamente usadas pelos reformadores". (TILLICH, 2004, p. 206).

3 Máxima de Hamlet ao se referir aos seus ex-amigos Rosencrantz e Guildenstern como joguetes de Cláudio, seu tio/padrasto. Nas palavras de Leandro Carnal: "Cláudio usa e abusa deles, jogando-os para lá e para cá. Quando se cansar, como fazemos com castanhas, ele engolirá ou cuspirá". (KARNAL, 2018, p. 138). Similar à atitude do ladino, rei da Dinamarca, Cláudio, o trono inglês usou Wycliffe para se escusar de pagar tributos ao papado; no entanto, quando se apercebeu que o discurso sobre o verdadeiro "senhorio" afetaria, mais cedo ou mais tarde, a estrutura governamental da coroa, o largou de lado, deixando-o cada vez mais só. (GONZÁLEZ, 2011, p. 487, 488). 
Todo [esse] período apresenta uma desintegração constante do ideal de unidade medieval marcada por duas características principais - de modo negativo, a perda da unidade internacional e da autoridade transcendente suprapolítica do papado; e de modo positivo, o crescimento dos Estados modernos e da unidade política nacional ( DAWSON, 2014, p. 59.)

Em síntese, o mesmo se seguiu em diferentes localidades da Europa. Gradativamente, se estendia o palco das Reformas Protestantes, que são, em suma, plurais e movidas por suas idiossincrasias nacionais (DAWSON, 2014, p. 141). Assim na parte Setentrional, Alemanha, se tem o estopim desse efeito dominó, reformador. Lutero tem, genuinamente, um deslizamento para o religioso - o que não impede de haver questões políticas e principescas, por parte dos representantes do Estado - e, com certo efeito psicocultural, herdados da confluência de seus estudos paulinos com as condições culturais e religiosas de sua época, como os flagelantes. A Suíça, à semelhança da Itália, era formada por confederações, "era praticamente um governo republicano" (DAWSON, 2014), fazendo de Zuínglio, principal representante desta, um reformador distinto de Lutero, "com muitos traços patrióticos, que eram mediados pela confluência da intelectualidade humanística e da política, para a nova programação reformadora" (GONZÁLEZ, 2011b, p.53). Paralelamente, na França, a Reforma foi mais controversa, e por fim, grassadas de políticas ardilosas.

Notadamente, a Reforma na Inglaterra tem suas peculiaridades bem acentuadas, tratando-se - assim como na França - de questões estritamente, políticas. A Reforma da Igreja Anglicana se inicia, propriamente, de um tratado político de Henrique VII, que unira seu filho, Artur, a Catarina de Aragão, herdeira espanhola. Entrementes, o sucessor do trono inglês faleceu, deixando-o para o próximo legatário, Henrique VIII. Assim sendo, o príncipe assumiu também a cunhada, reafirmando os laços com os espanhóis ${ }^{4}$. Todavia, Catarina só pôde dar uma filha, o que causou no rei preocupações políticas, levando-o a resolver a causa

4 Duas coisas são curiosas nesse enredo. Não era permitido o casamento entre cunhados, segundo a lei canônica, mas obteve-se uma dispensa papal que permitiu que o acontecesse. (cf. GONZÁLEZ, 2011b, p.71). O segundo caso curioso é o fato desse casamento ser congênere ao descrito pelo bardo, no enlaçamento de Cláudio e Gertrudez. (cf. KARNAL, 2018, p. 25). 
da forma, aparentemente, mais simples: divorciando-se, a fim de se casar com alguém que pudesse lhe dar um filho homem, Ana Bolena, com quem também não vingou o auspicioso plano. ${ }^{5}$

Para tal, Henrique VIII teve que desvencilhar-se da Igreja de Roma, decretando o "Ato de Supremacia", tornando a Igreja Estatal, a Igreja Anglicana. Após sua morte, o reino foi para as mãos de seu filho Eduardo VI, do terceiro casamento (GONZÁLEZ, 2011b, p.74), todavia, sua morte precoce legou o trono à Maria, filha de Catarina de Aragão, que apressadamente, restaurou os laços com Roma, e, perseguiu os protestantes até sua morte. Seguida por Elisabeth I, que num primeiro momento "não foi bem aceita, todavia, tinha a sucessão garantida por Henrique VIII que a assegurou ainda em vida" (WALTER; et al. 2006, p. 581). Seu zelo extremado pela nação foi um trunfo para conquistar a confiança de seus súditos. Quanto à religiosidade, Elisabeth tinha convicções espirituais forjadas na ala protestante, o que não foi motivo para perseguir católicos - ao menos de forma aberta. Pelo contrário, "ela procurou uma medida dialógica entre Roma e Genebra" (HÄGGLUND, 2003 , p. 253), incitando - direta ou indiretamente - uma disputa entre católicos e puritanos. Mesmo assim, "era uma posição anti extremista, permitindo razoável liberdade de opinião" (GONZÁLEZ, 2011b, p. 78), implantando um novo tempo. ${ }^{6}$

Doravante fica claro o background que, de sobremaneira, inspirou Shakespeare. Em vista disso, asseverou, tacitamente, Cordeiro:

Shakespeare não poupa esforços para ambientar o público na confusão que forma o enredo da trama. Para Hamlet, é-lhe impossível a fuga à prisão que é a Dinamarca, como também não é possível ao povo inglês fugir

5 É pouco provável que o casamento de rei inglês com Ana Bolena, tenha se dado por razões simplesmente emocionais. À bem da verdade, era uma postura demasiado política, pois, como figura de seu tempo, Henrique VIII, não se aprazia com a ideia de ter uma mulher como herdeira. Esse casamento gerou uma problemática muito grande para o mesmo, que se desgastou com o papado e, não pôde, perante este, desfazer-se do primeiro casamento, posto que fora validado por um papa e desfazê-lo seria uma atitude arriscada, comprometendo a doutrina da infalibilidade papal e, simultaneamente, contribuindo com as "assoladoras" críticas protestantes. (cf. KARNAL, 2018, p. 28).

6 No entanto, faz-se relevante a análise de Lindberg: "o caminho elisabetano entre os extremos católico e calvinista foi motivado politicamente, já que um negava a legitimidade da monarca enquanto o outro abolia o episcopado, o qual, segundo Elizabeth acreditava, apoiava a monarquia" (LINDBERG, 2017, p. 454). 
Teologia, cultura e literatura: uma análise da hamartiologia implícita na obra Hamlet, de 109 Shakespeare, a partir da teologia da fronteira de Paul Tillich

da ambiguidade que é a Inglaterra. Claramente, no texto, Shakespeare nos apresenta a disputa de três poderes: o catolicismo romano, a Reforma Protestante e o espírito da modernidade. (CORDEIRO, 2018, p. 114).

\subsection{Hamlet em face da intertextualidade bíblica}

Desde já se irrompem reflexões mais harmônicas com a Bíblia. De forma mais clara, com as leituras exegéticas que se têm aos montes, colidindo umas com as outras no cenário shakespeariano. Alguns aspectos dessa intrigante obra são por demais curiosos; pelo que "muitos autores assimilam a inspiração de Hamlet às Escrituras" (OLIVEIRA, 2014 , p. 124). Muito embora o texto de Hamlet seja impregnado de intertextualidade com a Bíblia, não é interessante afirmar a bíblia como sua fonte (BLOOM, 2004, p. 110).

No núcleo do que se chama intertextualidade, é sensível a presença de personagens - na verdade, reverberações e diálogos entre pessoas e fatos bíblicos que desaguam no texto - como Adão, Abel, Caim, Jefté, Davi, Jesus e, assim por diante. Enleando acasos fomentados na dogmática e presentes na Bíblia. À guisa de exemplo: "a maldição primeira" (OLIVEIRA, 2014, pp. 132-134) ou até mesmo a "regra de ouro" (GHIRARDI, 2015, pp. 86-87), que abate a ineficácia da vingança - tema relevante e paradoxal no poema ilimitado.

Harold Bloom, renomado crítico de Shakespeare, agora póstumo, acentuava muitas vezes esses links entre narrativas bíblicas e shakespearianas, mesmo que alegasse, imprescindivelmente, que a obra tenha três dimensões espirituais paralelas e em conflito - o catolicismo, o protestantismo e o hermetismo de Giordano Bruno (BLOOM, 2004, pp. 83-84). "Hamlet é o mais fino pó de Adão, mas continua sendo o Velho Adão, e não o Novo: essencialmente pó" (BLOOM, 2004, p. 131). Em outros autores e momentos, surge a seguinte leitura: "Hamlet representa o homem decaído, mas dispondo, em algum nível a imago dei; o rei Hamlet está no purgatório, esperando uma redenção; e, Cláudio é o próprio diabo, sem chances de salvar-se" (CORDEIRO, 2018, p. 63). Todavia, mesmo que componha em si, todas essas eminentes afeições, Hamlet é mais, e transcende a intertextualidade bíblica, pois não é, somente, um tipo de, Davi ou Jesus ele inaugura - um terceiro homem - o homem secularizado. (BLOOM, 2004, p. 131). 
Conclui-se que, paradoxalmente, Hamlet seja um medievo e, ao mesmo tempo, um homem pós-moderno. Nas palavras de Tania Alice Feix:

[...] a visão da liberdade de escolha, desenvolvida na tragédia, corresponde igualmente a uma concepção que marca a transição entre o realismo conceitual da Idade Média e o nominalismo renascentista [...]. Assim como na Pós-Modernidade, no Renascimento não existem mais verdades absolutas e a perspectiva humana - metaforicamente inventada nessa época - determina a visão do homem e do universo. Da mesma forma que a perda da crença nas Meta-Narrativas marca a transição entre Modernidade e Pós-Modernidade, a concepção de uma ordem teocentrista para uma perspectiva antropocentrista é um dos marcos da transição entre a Idade Média e o Renascimento. (FEIX, 2008, p. 203-204)

Dito isto, o homem secularizado, que está em face do antigo e do novo, é testemunha das variadas releituras da Bíblia, que é atualíssima, tal qual, Hamlet. O que dá azo para novas perspectivas hamartiológicas, o que será tratado em tempo oportuno.

\section{$2 \mathrm{O}$ construto teológico tillichiano}

\subsection{Teologia da cultura}

A finalidade desse capítulo é delinear um sistema teológico que trata do ilimitado, como tal; diferente de outros arcabouços dogmáti$\cos$ que falam da "preocupação última" do homem, a partir de uma linguagem que se propõe a ser unívoca ${ }^{8}$, tornando a divindade inerente aos limites do conhecimento humano. Falar sobre o Divino é um papel que deve ser cumprido com tamanha competência, que não se pode restringir a um tempo ou cultura. Nas palavras de A. A. R. da Silva: "Deus é um símbolo que deve aparecer e ser interpretado dentro de um

7 Preocupação última para Paul Tillich "é aquilo que determina nosso ser ou não-ser. O ser humano está preocupado de forma com seu ser e sentido, neste sentido, é uma questão de preocupação última, incondicional, total e infinita". Por isso, "deve-se estar preocupado de forma última com a mensagem cristã, ainda que, às vezes, esteja inclinado a atacá-la e rejeitá-la”. (cf. TILLICH, 2005, p. 28-32).

8 No nono capítulo da sua sistemática, Geisler versa sobre o pressuposto linguístico da Teologia, definindo como linguagem unívoca do Divino, aquela que tem o intuito de ser "totalmente igual ao que Deus realmente é". Inviabilizando-a em detrimento a linguagem análoga, que parte de uma similaridade da maneira como realmente é, posto que não caiba na mente limitada humana. (cf. GEISLER, 2015, p. 127). 
contexto cultural, porém jamais será esgotado, porquanto está muito além da cultura" (DA SILVA, 2006, p.131).

Dentro das perspectivas do arcabouço teológico tillichiano, três sobressaem, delineando toda lógica de seu pensamento. A primeira é o método de correlação. Isso se identifica de modo integral, com a dinâmica polar desta disciplina. Os dois polos são o "kerigma e a situação" (TILLICH, 2005, p. 21). Assim sendo, "o método de correlação explica os conteúdos da fé cristã através de perguntas existências e de respostas teológicas em interdependência mútua". Isto é a resposta deve ser dada apenas a perguntas feitas. ${ }^{9}$

"Tillich se via como um teólogo amalgamado entre as conceituações existencialistas e essencialistas" (TILLICH, 2004, p. 12). Nesse oximoro, aparece seu método, supradito, que chega a primeira asserção: "a única realidade com a qual podemos nos relacionar é o fato de existirmos, e isso é mais do que simples conhecimento" (TILLICH, 2009, p. 133). O que constitui uma organização lógica para respostas às perguntas feitas, é o engajamento na situação, da qual essas perguntas surgem, "fazendo-se participante do mundo, a partir das seções que tocam na vida de quem assim interage" (cf. TILLICH, 1992, p. 70). E, notadamente, percebe-se que o homem, que busca pela participação no real, está separado ou alienado tanto do mundo, quanto de si mesmo; e, é nesse segundo momento que Tillich aparece como essencialista, ao apresentar um homem separado dos outros, do tempo, de sua essência e de Deus.

Nessa dualidade entre essência e existência, emerge no plano tillichiano a segunda, dentre três perspectivas de seu sistema. A natureza da linguagem religiosa é um fator sine qua non para o discurso teológico, que "precisa ser expresso por meio de símbolos" (TILLICH, 1985, p. 30). Porém, para falar de símbolos religiosos é necessária a compreensão de fé "como estar possuído por algo que lhe toca de forma última ou incondicionalmente" (TILLICH, 1985, p. 34). Consequentemente, o objeto da teologia não pode ser produto de um discurso frio, mas

\footnotetext{
9 Ao discorrer assuntos como conceitos de paradigmas e a tarefa do teólogo como contextualizador, Sawyer chega à conclusão que a Teologia, fora a rainha das ciências, na medievalidade, contudo, foi destronada e faz seus pronunciamentos sem que ninguém a ouça. Agora, para retomar seu lugar de direito, ela precisa se tornar uma rainha/serva, a ponto de ouvir as outras disciplinas e aprender com elas, ensinando-as, também, mediante à uma correlação recíproca. (cf. SAWYER, 2016).
} 
daquilo que é ultimidade para o teólogo, tocando-o em "uma questão de paixão e interesse infinitos (Kierkegaard), transformando-nos em objetos sempre que tentamos transformá-lo em nosso objeto" (TILLICH, 2005, p. 29).

Assim sendo, o discurso religioso se utiliza de símbolos - que participam da realidade do ser que expressam - para abarcar todo conteúdo da preocupação suprema do homem, que como "incondicional deixa infinitamente atrás de si todo o âmbito do condicionado" (TILLICH, 1985, p. 32), apresentando um "Deus acima de Deus". (TILLICH, 1992, p. 140).

A terceira e consagrada perspectiva da teologia do teuto-americano é o princípio protestante. Sua urgência está ligada visceralmente à natureza do símbolo religioso, pois o símbolo representa algo do qual ele participa, mas que não é. Símbolos são condicionados e finitos, representando o incondicionado na medida em que abre novos níveis na profundidade do ser. Contudo, isso incorre num risco, a idolatria. Ora, o sagrado ou o separado é essencialmente um mistério e "em princípio nada tem a ver com a alternativa de bom ou mau: ele é tanto divino como demoníaco" (TILLICH, 1985, p. 14). É demoníaco toda vez que se dá a posição de absoluto ou de incondicional. E, diante desse quadro, "a Igreja tem o papel profético de denunciar o poder demoníaco na sociedade, mesmo que esteja inserida nela, como participante da mesma cultura" (TILLICH, 2006, p. 60). Dessa forma o princípio protestante reclama do absolutismo na cultura, como também da heteronomia, como na Igreja, por sinal.

\subsection{A coragem de ser}

Duas perguntas são capitais nesse momento: uma sobre coragem e outra sobre a ansiedade. Aquela, pode-se alegar "é autoafirmação 'a-despeito-de', isto é, daquilo que tende a impedir o eu de se afirmar" (TILLICH, 1992, p. 28). Enquanto a última diz respeito à angústia gerada pela finitude humana e a consciência própria de finitude. Nesse ínterim, uma relaciona-se com ser e a outra com o não-ser. Assim, faz-se verdadeira a assertiva: “o ser tem o não-ser 'dentro' de si mesmo, de modo que é eternamente presente e eternamente superado no processo da vida divina" (TILLICH, 1992, p. 28). 
Desse fato, nasce um questionamento, em primeira análise, pelo não-ser. Efetivamente, como se sustenta qualquer resposta a essa pergunta? Segundo Paul Tillich, a solução para esse inquérito está na antologia da coragem, da qual a ansiedade participa antologicamente. À vista disso, "coragem é a consciência da condição existencial" (TILLICH, 1992, p. 30). Em outros termos, são as percepção e experiência de finitude que partilham toda a humanidade.

Ansiedade, por assim dizer, é diferente de medo. Ora, o medo tem um objeto definido, enquanto a ansiedade nega qualquer objeto basilar do medo. "A ameaça da ansiedade é o puro nada". O que na teologia tillichiana compõe uma trinca, pois três são os tipos de ansiedades - no sentido ontológico, pois, existe também a ansiedade patológica que não será tratada no artigo em curso, mas é também, dissecada, por Tillich, em seu livro, A coragem de ser.

A primeira rotulagem da tríade da ansiedade chama-se ansiedade do destino e da morte. Essa é uma ameaça à autoafirmação ontica afirmação do ser, como existente. Distinguindo-se em duas, ela arranja a ideia de extinção biológica; como também, a problemática da contingencialidade e da acidentalidade do homem, frente ao destino. De igual maneira, a ansiedade da vacuidade e insignificação assola a natureza humana, contudo, por vieses dispares, intentando contra a "autoafirmação espiritual". A terceira ansiedade fala de condenação e culpa, atacando o homem na sua consciência, a partir do moralismo (TILLICH, 1992, p. 43-44).

De forma antagônica, "a coragem pode mostrar-nos o que é o ser" (TILLICH, 1992, p. 6). Para tal, Tillich elenca conceitos de coragem que vão de Platão à Nietzsche. Em Platão, coragem tem em seu âmago as ideias de animosidade, razão e desejo. No aristocrata aristotélico, a coragem é virtude, que pode ser exposta pelo sacrifício. Para o aquinate, é dom de Deus. Para os estoicos, coragem se confunde com sabedoria. Já em Spinoza, "é uma expressão do ato essencial de tudo que participa do ser, a saber, autoafirmação" (TILLICH, 1992, p. 19). E, em Nietzsche, coragem perfaz o que ele chama de vontade de potência.

Posto isto, Tillich enseja a coragem de ser como uma parte, como resultado da correlação entre individualização e participação (TILLICH, 1992, p. 67). Observa-se que a coragem começa seu ser na centrali- 
zação de um ser individual que, não obstante, só pode ver como reais as seções do mundo, das quais ele participa (TILLICH, 1992, p. 70). A coragem de ser como uma parte pode ser vista em uma sociedade coletivista, que se depara com ansiedades e situações comuns - tendo assim - a participação, como meio de superação do medo do nada. Contundo, no afã de participar o se fazer parte de um grupo, perde-se a individualidade, não podendo ser mais coragem, uma vez que coragem é autoafirmação do ser.

Como segunda alternativa, ser como si próprio é a capacidade de individualização que foi bem expressa pela filosofia existencialista. Por isso, "a filosofia da existência experimentada restabelece a consciência da separação entre o finito e o infinito" (TILLICH, 2009, p. 144), a base da angústia e do desespero. Não compreendendo, contudo, o desenlace desse drama. Pois cortado da participação do mundo, e afirmando apenas a individualização; ou respondendo a vida como resultado, unicamente do que faz consigo mesmo, o existencialismo se torna vazio e sem respostas para a correlação de essência e existência (TILLICH, 1992, p. 115).

O único caminho que parece plausível nessas condições é a fé, englobando participação mística e confiança pessoal. Ela é a coragem de aceitar a aceitação. O risco que de aceitar que existe um elemento do incondicionado, tornando-se este, a preocupação suprema, na concretude e integralidade do ser (TILLICH, 2009, p. 66). A fé como risco "baseia-se num fundamento que não é arriscado: a consciência do elemento incondicional em nós e no mundo" (TILLICH, 2009), tragando corajosamente a dúvida, a morte e a culpa no ser, em detrimento do não ser.

\section{A nova hamartiologia shakesperiana e sua interface com uma teologia que diz respeito à vida}

\section{1 ser ou não ser como monólogo da ontologia da coragem}

Hamlet, consagrada peça dramática shakespeariana, tem como catalizador de seu enredo, a vingança. O príncipe Hamlet precisava vingar seu pai, que fora assassinado por seu tio, Cláudio; e nesse plano de vingança se desenvolve a trama (SHAKESPEARE, 2010, p. 67). Isso infere a uma problemática social-religiosa da época. Esta enseja 
a honra do nobre em detrimento ao serviço de um bom cristão. Como afirma Ghirardi:

O paradoxo, entretanto, residia no fato de que os mesmos nobres de que se exigia prontidão para a violência estavam, também, simultaneamente, e com igual força, obrigados a serem bons cristãos e, portanto, a abandonar qualquer pensamento de vingança contra aqueles que os insultassem. $\mathrm{O}$ mandamento de oferecer a outra face, expresso em Lucas VI, 29, era tão intrínseco à ideia prevalente do que significava seguir o Cristo que não era possível desconsiderá-lo sem enorme custo social. (GHIRARDI, 2015, p. 87).

Por essa e outras ${ }^{10}$ o príncipe fica conturbado, sendo levado a reflexões desalegres da vida. O sentimento de estar aprisionado e limitado, mesmo possuindo potencialidades fulgentes, pois se tornam impraticáveis pelos maus sonhos (SHAKESPEARE, 2010, p. 97-98). O desejo de dar fim ao sofrimento, pela morte voluntária e a crise pela não aprovação de Deus (SHAKESPEARE, 2010) chegam ao clímax no monólogo ser ou não ser - que, segundo Harold Bloom, não comtempla, seriamente, o suicídio (BLOOM, 2004, p. 42).

Sem direito de escolha, como ser humano que é, saboreia os causos do destino que lhe acometem um estado de ansiedade, com bravura e coragem de ser como si próprio - individualização ou coragem autônoma - Hamlet traça um plano, que no seu interior, tende apenas a objetivar ou coisificar pessoas, fazendo-lhe indiferente a situação humana e afastado do mundo. Assim, ele incorre em mais um abismo, a ansiedade da dúvida e insignificação, posto que, a cada dia o teatro da vida se torna mais hostil. Ao final da tragédia, enfrenta a ansiedade da culpa e da condenação; pelas mortes seguidas por ele.

Toda essa trama sai e retorna, ciclicamente, da pergunta: ser ou não ser? Essa é a questão, ficar entre uma escolha: "sofrer estoicamente, ou tomar armas contra o mar" (BLOOM, 2004, p. 44). Na leitura do historiador brasileiro, Leandro Karnal, a ponderação principesca é sobre matar ou não o rei, pois que as consequências eram diversas (KARNAL,

10 Encontros acidentais que acometiam a vida do príncipe melancólico dinamarquês, como: a recente e inesperada morte do pai; o casamento de sua mãe com seu tio, de forma tão abrupta; e agora, o fantasma requerendo vingança. (cf. SHAKESPEARE, 2010). 
2018, p. 97). Nisto, ele faz uma aplicação à vida corriqueira, levando o solilóquio ao nível existencial - à crise que é real em todo homem, pela alienação de seu ser essencial. Isso é latente na asserção de Bloom: "apesar de estar carente de fé, tanto em relação à linguagem quanto em relação ao eu, e desprovido de alianças transcendentais, Hamlet continua a crer na verdade a que o teatro é capaz de induzir" (BLOOM, 2004, p. 41). Dessa forma, os assustadores sonhos, pós-morte, do monólogo, não aterrorizam por um conteúdo manifesto, mas por simbolizar a ameaça do nada, a morte eterna (TILLICH, 1992, p. 32).

Se o "pecado é a alienação de si mesmo, em proveito de outro homem", como afirma Tillich (2006, p. 25), Hamlet, imerso em sua individualização, precisa de salvação, de uma nova realidade de vida, gerida pela coragem de ser. A coragem de aceitar a aceitação, mesmo sendo inaceitável (TILLICH, 2009, p. 174). Inaugurando, assim, "uma realidade curada, dizendo sim no encontro com o nada, com a angústia e o desespero" (TILLICH, 2006, p. 24).

Para Bloom, Hamlet alcançou esse estado de Novo Ser, que perpassa a ruptura entre ser essencial e existencial na frase "seja o que for!"; pois ele empurra de lado o medo natural da morte, enfrentando-a corajosamente. Assim, sua morte não é trágica. É apoteótica! (BLOOM, 2004, p. 90).

\subsection{Ofélia e a releitura do suicídio}

Em sua História do pensamento cristão, Paul Tillich traça algumas linhas sobre a doutrina do pecado na tradição católica. Propriamente, ele faz uma distinção entre as hamartiologias católica e protestante. Nesta, pecado é singular. É falta de fé e resultado da queda universal e trágica, o que faz separação entre o homem e Deus - em termos tillichiano, a alienação do ser, em detrimento do fundamento de seu ser. Aquela, a Igreja romana, faz menção a pecados - plurais - que podem ser perdoados ao se confessarem ao sacerdote (TILLICH, 2004b, p. 215). Por isso, no caso do protestante faz-se imprescindível a conversão, a transformação do ser e a reunião com Deus. Pois o homem, enquanto ser, foi criado bom, despencou na queda universal - "baseada na liberdade e no destino dos seres humanos" (TILLICH, 2009, p. 173) - e necessita de salvação, um salto além da essência e da existência. 
Essa explicação se faz relevante, na medida em que o drama do bardo se estende por espaços geográficos e culturais, católicos. Dito isto, fica claro, no enredo que se perfaz, inferências da teologia romana, enleando uma série de pecados ocultos, que na trama vão encontrando suas consequências. À guisa de exemplo: o fratricídio de Cláudio, o casamento "incestuoso de Gertrudes", o homicídio de Hamlet e dentre esses, uma sequência de desprazeres na teatralidade de Elsinore.

Contudo, o suicídio de Ofélia parece chamar atenção suficiente para o intuito deste artigo. A pobre donzela não passa de um jogo para seu pai e o amado príncipe. O primeiro a faz de espiã para seus intentos palacianos (BLOOM, 2004, p. 48). Já Hamlet, simula loucura; a insinua, em certo momento, como dissimulada; e, depois de mostrar traços de admiração e amor, rebaixa-a quase ao nível de uma prostituta (KARNAL, 2018, p. 117), levando-a, por essa atitude monstruosa à loucura (BLOOM, 2004, p. 51).

Paulatinamente, os fatos se estreitam, e "no final, contudo, Ofélia foi a grande derrotada" 11 , que tão depressa, abandona o silencio e expressa sua dor resultado do desamor de Hamlet, que tem seu fim no lago. $\mathrm{Na}$ morte de Ofélia que não luta pela afortunada vida. Tudo isso, por causa do pecado, não como feitos moralmente rechaçados pela sociedade, mas como alienação do ser essencial, que de fato, constrói relações injustas pois destroem as reivindicações inerentes ao ser (TILLICH, 2004a, p. 82).

Não sendo capaz de suportar a ansiedade e o desespero da culpa e do insignificação na existência, ela se entregou, estoicamente, ao não ser, o país ignorado - ou o nada. Todavia, em linguagem religiosa, ela precisava de perdão. Precisava perdoar a si mesma e "aceitar a aceitação do inaceitável, que é a base para a coragem da confiança" (TILLICH, 1992, p. 125). Pois, o poder de Deus está em superar a separação.

\section{Considerações finais}

"Há mais coisas, em céus e terras, do que sonhou nossa filosofia", dizia Hamlet (SHAKESPEARE, 2010, p. 75). Da mesma natureza,

\footnotetext{
11 "Laertes longe na França, Polôlonio, seu querido pai, assassinado pelo amor de sua vida e Hamlet enviado, às pressas para Inglaterra”. (cf. KARNAL, 2018, p. 117).
} 
pode-se dizer: há mais coisas em Hamlet e em Tillich do que sonha açambarcar esse artigo, contudo, seguem as seguintes considerações.

A doença ou o pecado como alienação está manifesta em todo enredo: começa pelo rei Hamlet, separado de Gertrudes pelas Guerras (BLOOM, 2004, p. 64); passa por Cláudio separado de qualquer compaixão por seu irmão, por conta de suas concupiscências (BLOOM, 2004, p. 64); desaguando no distanciamento do príncipe Hamlet, das camadas mais reais da vida, assumindo tudo como um teatro, que separado do amor ,maltrata Ofélia; e esta, por sua vez, afastada de qualquer sentido da vida, se entrega a possibilidade de não-ser, por não suportar a ansiedade e o medo da insignificação. Contudo, é cabível o parônimo: Hamlet está entre o ladino e o paladino, atual, como já foi dito, ele abre caminhos e novos enfoques para a hamartiologia contemporânea, ou seja, ele se apresenta como "humano, demasiadamente, humano" (NIETZSCHE, 2017, p. 3), consideração que em muito a Teologia esquece.

\section{Referências Bibliográficas}

AGOSTINHO, Santo, de Hipona. Confissões. Td. J. Oliveira e A. Ambrósio de Pina. $2^{\mathrm{a}}$ ed. Petrópolis: Vozes de Bolso, 2013.

BLOOM, Harold. Hamlet - poemas ilimitados. Td. José R. O'shea. Rio de Janeiro: Objetiva, 2004.

CORDEIRO, João Roberto Marques. Aspectos do cristianismo no texto dramático Hamlet de William Shakespeare. 2018. 126 f. Dissertação (Mestrado) - Programa de Pós-Graduação em Ciências da Religião, da Universidade Federal do Sergipe, São Cristóvão, 2018.

DA SILVA, Antônio Almeida Rodrigues. "Teologia da cultura: a experiência do incondicionado nas multiformes expressões culturais". In: Revista Eletrônica Correlatio, n. 9, p. 125-138, 2006.

DAWSON, Christopher. A divisão da Cristandade - da Reforma Protestante à Era do Iluminismo. Td. Márcia X. de Brito. São Paulo: É Realizações, 2014.

. Criação do Ocidente - a religião e a civilização medieval. Td. Maurício G. Righi. São Paulo: É realizações, 2016.

FEIX, Tania Alice. Hamlet em sua época e ensaio.hamlet, da cia dos atores: modernidade e pós-modernidade teatral. Revista Urdimento, n. 11, p. 203213, 2008. 
GEISLER, Norman. Teologia Sistemática. Td. Marcelo Gonçalves e Luís Aron de Macedo. Rio de Janeiro: CPAD, 2015.

GHIRARDI, José Garcez. "Somos todos rematados canalhas - notas sobre vingança e justiça em shakespeare". In: Anamorphosis. v.1. n. 1, p. 85-98, 2015.

GONZÁLEZ, Justo L. História ilustrada do Cristianismo - A Era dos mártires até a Era dos sonhos frustrados. Td. Key Yuasa e Hans Udo Fuchs. $2^{\mathrm{a}}$ ed. São Paulo: Vida Nova, 2011.

. História ilustrada do Cristianismo - A Era dos reformadores até a Era inconclusa. Td. Itamar N. de souza. $2^{\text {a }}$ ed. São Paulo: Vida Nova, 2011.

HÄGGLUND, Bengt. História da Teologia. Td. Mário L. Rehfeldt e Gládis K. Rehfeldt. $7^{\text {a }}$ ed. Porto Alegre: Concórdia, 2003.

KARNAL, Leandro. O que aprendi com Hamlet - porque o mundo é um teatro. Rio de Janeiro: LeYa, 2018.

LINDBERG, Carter. História da Reforma. Td. Elissamai Bauleo. Rio de Janeiro: Thomas Nelson Brasil, 2017.

NIETZSCHE, Friedrich. Humano, demasiado humano - um livro para espíritos livres. Td. Paulo C. de Souza. São Paulo: Companhia de bolso, 2017.

OLIVEIRA, A. C. de Souza. A maldição primeira e outros intertextos bíblicos em hamlet, de shakespeare. Estudos anglo americanos. $n^{\circ} 42$, p. 123-142, 2014.

SAWYER, James. Uma Introdução à Teologia - Das questões preliminares, da vocação e do labor teológico. Td. Estevan F. Kirschner. São Paulo: Vida, 2016.

SHAKESPEARE, William. Hamlet. Td. Barbara Heliodora. São Paulo: Abril, 2010

TILLICH, Paul. A coragem de ser. Td. Eglê Malheiros. $5^{\text {a }}$ ed. São Paulo: Paz e Terra, 1992.

. Amor, poder e justiça - análises ontológicas e aplicações éticas. Td. Sérgio P. de Oliveira. São Paulo: Novo Século, 2004. dal, 1985

. Dinâmica da fé. Td. Walter O. Schlupp. $3^{\mathrm{a}}$ ed. São Leopoldo: Sino-

. História do pensamento cristão. Td. Jaci Maraschin. $2^{\mathrm{a}}$ ed. São Paulo: ASTE, 2004

Teologia da cultura. Td. Jaci Maraschin. São Paulo: Fonte Editorial, 2009.

Teologia Sistemática. Td. Getúlio Bertelli e Geraldo Korndörfer São Leopoldo: Sinodal, 2005. 
Textos selecionados. Td. Eduardo Proença. São Paulo: Fonte Editorial, 2006.

WALTER, W. et al. História da Igreja cristã. Td. Paulo Siepierski. São Paulo: Aste, 2006. 